DOI: 10.21005/pif.2021.48.B-02

\title{
“SMALL IS BEAUTIFUL" NEW TRENDS IN ARCHITECTURE AND INTERIOR DESIGNS
}

\author{
„MAŁE JEST PIĘKNE” NOWE TENDENCJE PROJEKTOWANIA \\ ARCHITEKTURY I WNĘTRZ
}

\author{
Justyna Juroszek \\ dr inż. arch. \\ Wyższa Szkoła Techniczna w Katowicach \\ Wydział Architektury Wnętrz \\ Katedra Projektowania Architektury Wnętrz
}

Author's Orcid number: 0000-0002-7157-1180

\section{ABSTRACT}

The article outlines how views on residential architecture have changed in recent years. Sustainable development, ecology and balance are recently trendy concepts that have also been reflected in architecture. They manifested themselves through a new approach to designing the living space. It began to be approached more practically, inventively and creatively. Initially in the United States, and then in other countries, the architectural trend known as Tiny Houses began to appear. It referred to minimalism, savings and anti-consumerism. In Poland, this designing trend is still relatively new, but it is a challenge for the future in architecture.

Keywords: architecture, Tiny Houses, spatial restrictions, designing.

\section{STRESZCZENIE}

W artykule nakreślono, jak w ostatnich latach zmieniają się zapatrywania na architekturę mieszkaniową. Zrównoważony rozwój, ekologia, równowaga to modne ostatnio pojęcia, które znalazły odbicie także $w$ architekturze. Przejawiły się one poprzez nowe podejście do projektowania przestrzeni życiowej. Zaczęto do niej podchodzić bardziej praktycznie, pomysłowo i kreatywnie. Początkowo w Stanach Zjednoczonych, a następnie w innych krajach zaczął się pojawiać nurt architektoniczny określany mianem Tiny Houses. Nawiązywał on do minimalizmu, oszczędności oraz antykonsumpcjonizmu. W Polsce taka tendencja projektowania jest jeszcze stosunkowo nowa, jednakże stanowi ona wyzwanie przyszłości w architekturze.

Słowa kluczowe: architektura, małe domy, ograniczenia przestrzenne, projektowanie. 


\section{INTRODUCTION}

How has the perception of architecture changed in recent years? Have the tastes of society changed in this respect? How can architects help the communities they live in? Increased activities for environmental protection, increased awareness of human impact on nature and popularization of a minimalist approach to life have resulted in a change in the approach to the concept of home as a residence. At the same time, during economic crisis, people more and more often choose small, economic houses, often energy-efficient or passive. All these factors contributed to the development of the concept of building small houses called Tiny Houses, being a response to the expectations of the present society, aware of its own impact on the environment.

\section{METHODOLOGY}

The article uses the method of literature and documentation analysis to show how the new trends in architecture, related to the design of residential spaces in a limited space, will develop. According to the provisions of Article 29 of the Construction Law, the following buildings does not require a building permit: detached one-story buildings for individual recreation, understood as buildings intended for periodic rest, with a surface area of up to $35 \mathrm{~m}^{2}$, the number of such objects on the plot may not exceed one for each $500 \mathrm{~m}^{2}$ of the plot area (the Construction Law).

Therefore, the construction of a small house does not require time-consuming bureaucratic formalities. Whenever the site development plan allows it, it is possible to erect a small residential building only on the basis of a notification. In principle, it should be an individual recreation building, however, by using appropriate modifications, it is possible to adapt such an object for year-round use. Thus, small houses become an excellent alternative to expensive living space in a large city. It is also worth mentioning that adapting the mini-house to the needs of its users also requires proper planning of its space. Folding tables, pull-out benches or drawers hidden in secret nooks and crannies are the solutions commonly used in mini-houses.

\section{LITERATURE REVIEW}

The problems of small houses are quite widely described in foreign literature, concerning not only architecture, but also technology, construction and even sociology. It is worth mentioning that this subject was discussed by Michael Joseph Stratton II in the monograph "Development of a Tiny House Design Tool to Increase Safety, Efficiency, and Cost-Effectiveness", where the technical approach to designing the small houses is discussed, taking into account the climate and energy efficiency of buildings. On the other hand, Daniel Hutchinson in the article "Struggling for Spatial Authenticity: an analysis of the tiny house movement" or Jasmine Ford and Lilia Gomez-Lanier in the article "Are Tiny Homes Here to Stay? A review of Literature on the Tiny House Movement "outlines the advantages of living in small houses. Among Polish authors, Arkadiusz Wyrzykowski wrote about the minimalist trend in architecture in the article "Tiny houses or (non) minimalist design", showing the history and approach to the problem of constructing the small houses (Wyrzykowski A. 2019, pp. 85-106) as also by segregating them according to their specificity and location.

Agata Twardoch from the Silesian University of Technology also dealt with the issues related to the architecture of mini-houses in the article "Less means more, or less for more. Social spaces and psychological approach to the issue of micro-apartments", where the author outlined the issues of micro-apartments in a cross-cutting view, dealing with both history - illustrating current trends, as well as showing demographic, social and psychological conditions of life in a small area. Minimalism as well as designing small houses in Poland is an increasingly common phenomenon. People want to live comfortably and economically, using the successful models of world architecture. The abovementioned literature review illustrates what are the design trends in the world and what advantages result from living in a small space. In her article, she tries to illustrate the technical, social and economic possibilities in designing the mini-houses in Poland. 


\section{THE ARTICLE OBJECTIVE}

Do the spatial limitations in Poland allow for the constructing the architecturally interesting buildings that meet the requirements of users? Will the new trend of pro-ecological society revolutionize the view on architecture? Can a small house size give us a sense of security? How to design a house to create a functional and spatial structure that will provide us with appropriate aesthetic conditions, ensure mental health, ensure faster regeneration, and intellectual fitness? Are we able to provide ourselves with all modern amenities in a small space? In recent years, the view of the world have changed, as well as the needs of physical and psychological nature. People began to evaluate their own living space in a new way - the house and its surroundings. The concept of understanding the architecture has also changed and now the house should be first of all functional. Small houses of living area up to $35 \mathrm{~m}^{2}$, which can be erected in Poland without a building permit, but only on the basis of a notification (Act of July 7, 1994, Construction Law Art. 29, i.e. Journal of Laws 2020, item 1333) became a reflection of the changing needs. The houses are often equipped with multifunctional furniture at the individual request, which would meet the need for architectural functionality. The recognition of these changes made architects want to contribute to a new chapter in architecture, which is designing the residential buildings of a very limited living area.

\section{THE ORIGIN OF MINIMALISM}

According to the definition suggested by A. Twardoch: Minimalism is the way to simplicity, reducing unnecessary things, activities and duties in every area of our life. Minimalism is also a manifesto and a trend: throw away everything unnecessary, give up the consumptive lifestyle, be eco. It also has a symbolic dimension: a mixture of history, hipster, ecology, economy and morality. It allows the inhabitants of mini-houses to feel superiority significantly exceeding the small size of a flat (Twardoch A. 2017, p. 111). Minimalism makes life easier and organizes it. In 1984, the American philosopher Henry David Thoreau built a cabin near Concord, Massachusetts, in which he lived for 14 months. In many ways, his philosophy symbolizes the reasons why men and women seek refuge in very small houses, away from the stress and pollution of cities. While excess and "luxury" are the driving force of some societies, more and more people feel the need to scale to the bare minimum, to live in nature, in the sounds of the forest, against the rising sun. Where Thoreau's reasoning had to do with the philosophy of life, it was an attempt to return to the basics, the motivation that also seems to govern the Cabanon de vacances built in 1951-1952 at Roquebrune-Cap-Martin on the French Riviera by Le Corbusier (Fig. 1,2,3,4). The design of the object $3.66 \mathrm{~m} \times 3.66 \times 2.66 \mathrm{~m}$ is considered the smallest example of its author's modular thinking and standardized construction methods, who called it maison (home) - because it took into account its natural surroundings. For Le Corbusier, it was an experiment based on the idea of the Modulor, a system of human proportions he invented in 1943. Despite its simplicity, the Cabanon is the result of thorough thinking with equipment arranged in a spiral form. The example of Thoreau and Le Corbusier present combination of philosophy and architecture as an important character of cabins (Jodidio P. 2014, p. 7).

The cabin, as the name suggests, was to be a home connected with nature. The trend of Tiny Houses that appeared in the United States several decades ago is considered to be the beginning of designing the mini houses. It was a real trend or - as some authors call it - a "phenomenon". The term "small-house movement" or "Tiny House movement" is used to describe the social and architectural movement related to inhabiting in small houses associated with anti-consumerism. These were the mobile homes of an area from a dozen to a maximum of thirty square meters, most often built of sea containers, skeleton structures, semi-trailers or trailers. These houses are equipped with multifunctional, custom-made furniture: drawers hidden in the floor, a folding table, a fold-out sofa with many storage places. They often had a sleeping place in the form of an entresol over the kitchen and sanitary part. It is worth emphasizing that some authors see the beginnings of the minimalist trend in Japan. For example, N. Pollock points out that the Japanese, like no others, have mastered the ability to build successful living spaces on very small plots of land. Due to the limited area on flat surfaces and many people wanted to live there, the land is very valuable, especially in Tokyo and other big cities, where prices remain very high, despite ups and downs of the country's economy (Pollock $\mathrm{N}$. 2015 p. 5). In Japan - where every centimetre of space is valuable - a home must be small but 
functional. The young generation of Japanese architects, however, have a much more courageous and unconventional approach to creating designs that are amazing. It was they who initiated the era of constant experimentation: surprising wall angles, facades that are closer to spaceships, or the wise use of windows of the strangest shapes. In Poland, multifunctional design was started in the 1930s, when there was a need to arrange very small apartments. The concept of designing the multifunctional living spaces, which are minimalist at the same time, was born in Poland by combining experiences from distant parts of the globe - America and Japan.
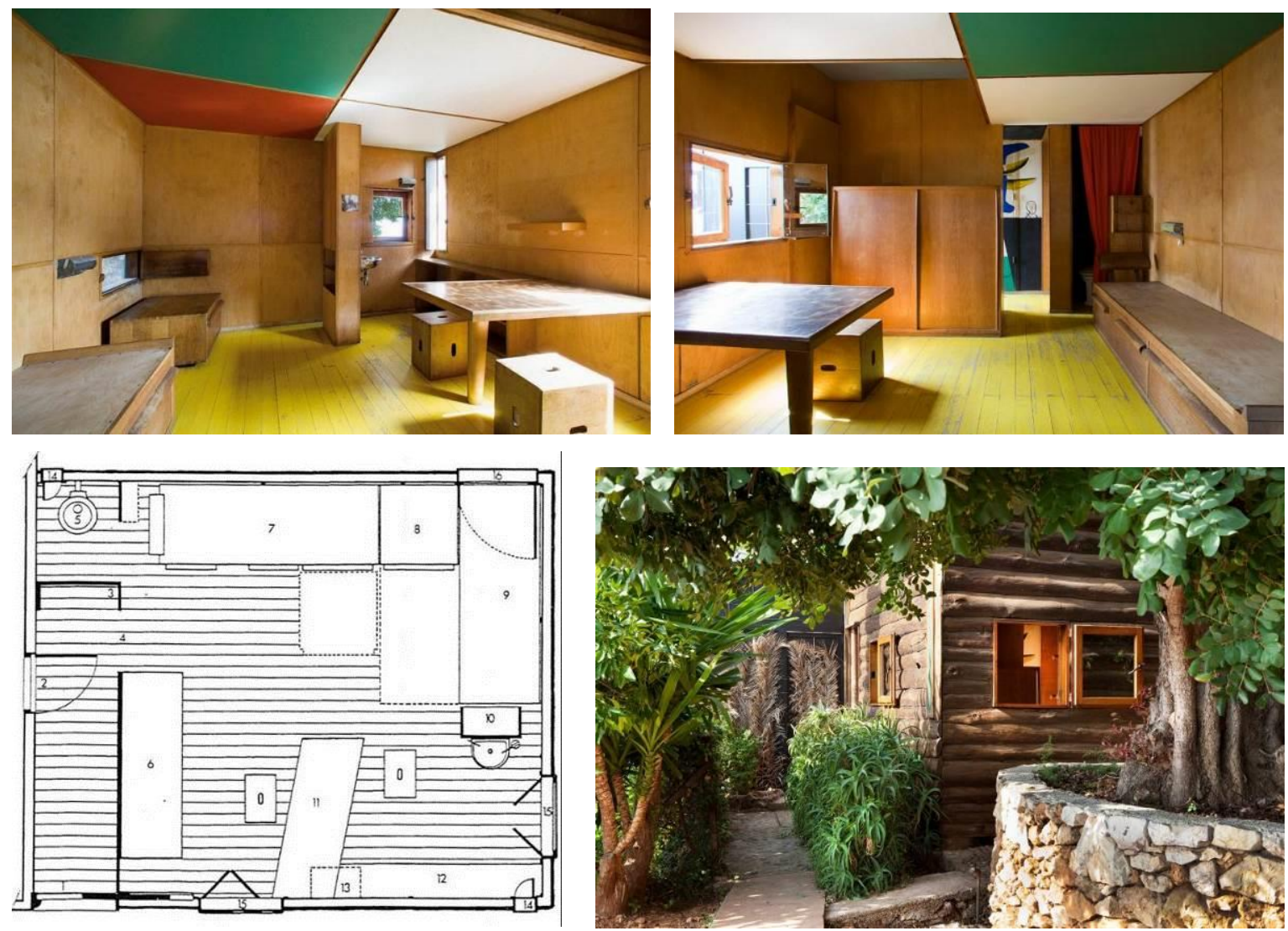

Fig. 1,2,3,4 France, Roquebrune-Cap-Martin, designer: Le Corbusier, 15,84 m2, 1951-1952. Source: https://www.clarkrendall.com/2021/05/25/le-corbusier-cabanon-de-vacances/

Ryc. 1,2,3,4. Francja, Roquebrune-Cap-Martin, projektant: Le Corbusier, 15,84 m2, 1951-1952. Żródło:

https://www.clarkrendall.com/2021/05/25/le-corbusier-cabanon-de-vacances/

\section{SOLUTIOS FOR POSSIBILITY OF ECONOMIC CONSTRUCTION OF MINI HOUSES}

New expectations of the society - small, functional and economic houses - resulted in searching for the simplest solutions that would satisfy these expectations. Modular, timber frame or container houses have become a good solution. Thanks to good thermal insulation, these houses are very energy-efficient, what is one of the most important criteria for the present users.

In the countries of Europe or North America, i.e. in highly developed regions, where residents experience all the privileges and inconveniences of living in a highly urbanized space, the preference for natural scenery is unique. The term "natural" or "man-made" becomes a unique element in the perception and categorization of the external environment (Schneider-Skalska G. 2004, p. 54). Natural elements in a residential environment are preferred. The healing effect of nature's elements in the human environment has been proven. It both has an impact on mental and physical well-being, as 
well as intellectual performance, willingness to act, faster regeneration after physical and mental fatigue, and speeds up recovery in the event of illness. When designing a functional and spatial structure, we provide aesthetic benefits, identification and stimulating values, creating conditions for meeting the need for contacts with others and the need for intimacy, independence and cooperation.
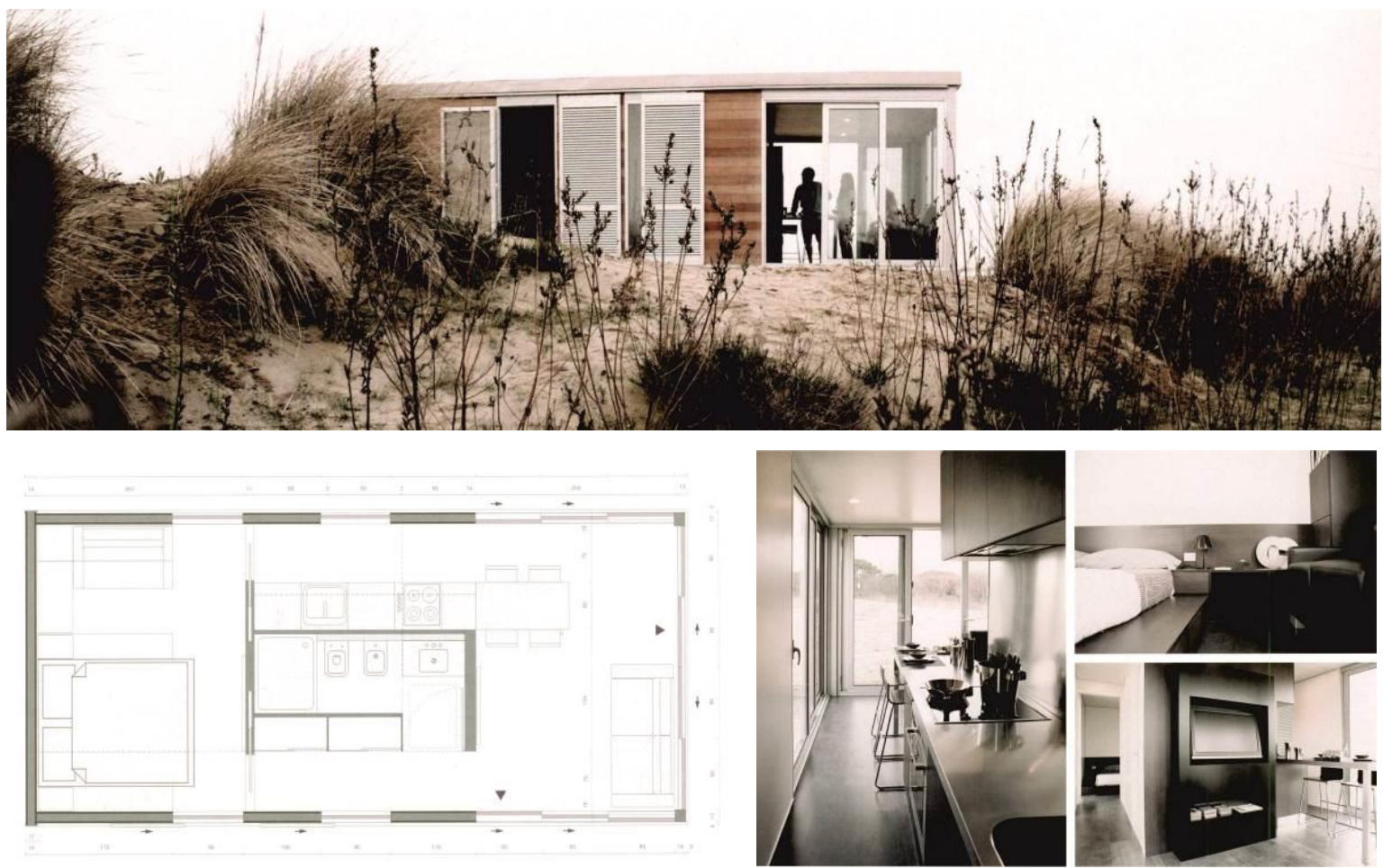

Fig. 5, 6,7,8,9. Italy, designer: Hangar Design Group, 34 m2, 2008. Source: Jodidio P. et.al. 2010 pp. 140-143. Ryc. 5, 6,7,8,9. Włochy, projektant: Hangar Design Group, 34 m2, 2008. Źrodło: Jodidio P. et.al. 2010 pp. 140-143.

Mini modular houses usually do not require any foundations, but only a temporary connection of electricity and water, e.g. from the neighbouring building. Sewage can be discharged by a pump or to a septic tank. Currently, modular houses are most often constructed for the needs of summer houses in places close to nature, such a lake or a forest (Fig. 5,6,7,8,9). Contact with nature is the determinant that gives us mental health, peace, and directs intellectual development. Many people also decide to erect year-round summer houses in city centres in allotment gardens. In large urban agglomerations in Western Europe, the lease of land in city centres to set up a dozen or so yearround modular houses for further rental has also become popular. Mini modular houses are made of prefabricated components, i.e. ready-made components prepared in the factory. The prefabricated components include not only walls and ceilings, but also larger components constituting up to half of the house. These buildings are most often made in two structures: skeletal, where the core is made of wood or steel, or made of expanded clay, i.e. a steel frame filled with burnt clay mixed with concrete. Ready modular houses consist of specific components that are connected to each other at the construction site on specially prepared foundations. The construction site does not require the employment of a supervision inspector, and the work advancement does not depend on weather conditions. The wooden frame technology dominates the market, of course, due to the ease of manufacture, light-weight and strength of the structure. Modular houses of expanded clay aggregate structure are less popular due to the higher cost of manufacture and transport. Regardless of the type of technology adopted for building the house, its durability will be comparable to that of a typical singlefamily house, thanks to the use of appropriate protection and thermal insulation of walls and ceilings as well as protective insulations in these objects. It is worth mentioning that modular concrete houses 
will show a slightly higher durability, fire resistance and high heat accumulation, i.e. parameters that characterize brick houses. Therefore, if a mini-house is to be used as a year-round flat, it is beneficial to invest in a modular house made of expanded clay concrete. Development of modular construction, a change in technology and a high degree of prefabrication mean that these houses are no longer associated with cheap, habitable containers and more and more often look like state-of-the-art, allyear-round objects. Modular buildings have long ceased to be seasonal houses. The current technology and new materials allow for the creation of year-round buildings for which preparation of the foundation slab is the only brick work to make. State-of-the-art modular houses are not only visually attractive and fit perfectly into the landscape of urban architecture, but also more and more often meet the standards of energy-saving construction. They reduce charges related to the required thermal energy, and the solutions used for assembly and prefabrication also allow to reduce the maintenance cost of the building. Some of state-of-the-art modular homes can have a standalone heating system and huge, modular windows that provide access to natural light. The interiors of such houses are characterized by functionality in design of the utility structure as well as in interior fittings. Modern interiors are designed so that the natural environment can penetrate from the outside to the interior. This is ensured by large, modular windows, often also roof windows. Thanks to this, when living in a small house, we have a sense of security, but also use the surrounding landscape to relax and calm down.
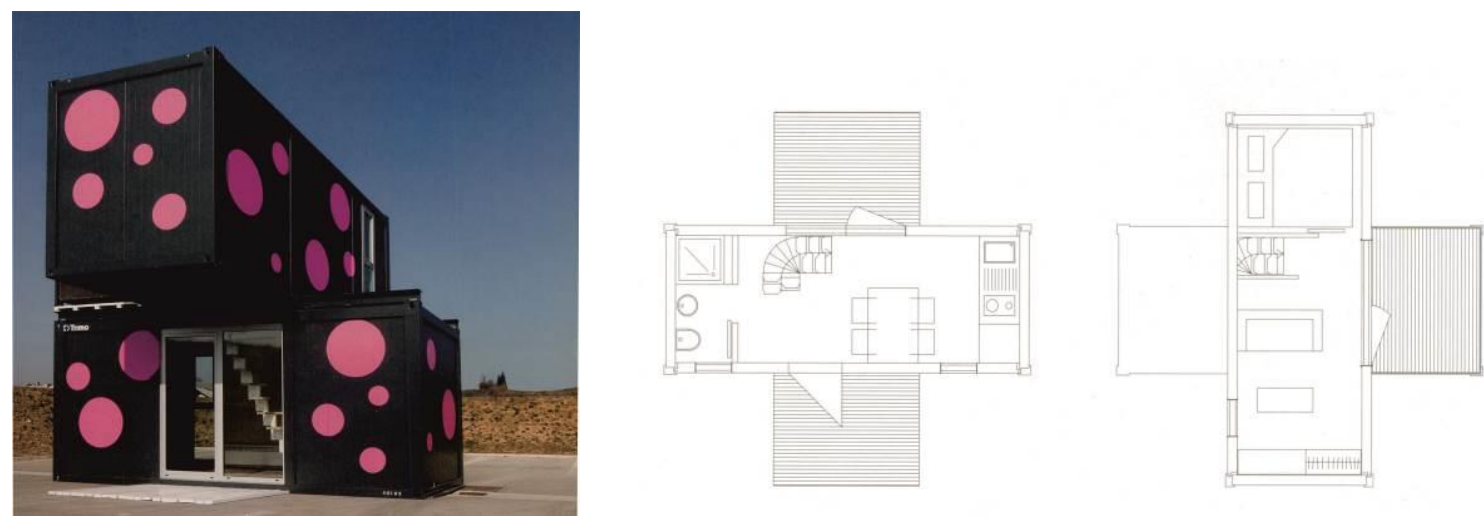

Fig. 10, 11,12. Sweden, Stockholm, designer: Jure Kotnik $29 \mathrm{~m}^{2}$, 2008. Source: Galindo M. et al. 2010, pp. 150-153 Ryc 10, 11,12. Szwecja, Stockholm, protektant: Jure Kotnik 29 m², 2008. Źródło: Galindo M. et al. 2010, pp. 150-153

Modular houses - the container ones (Fig. 10,11,12) are other interesting solution. Sea containers, new ones or used are applied for their construction. The container structure is a self-supporting steel frame (being a skeleton) made of closed cylindrical profiles. The profiles are sanded and protected with an anti-corrosion varnish. External walls, ceiling and a floor are made of galvanized steel sheet, stiffened with side reinforcements and filled with insulating material - usually mineral wool or polyurethane insulation in the form of PUR resin boards. It is worth mentioning that containers are insulated in the same way and with the same materials as traditional buildings. From the inside of the partitions, chipboards, laminated boards or plasterboards are used. There are many possibilities to finish a container house from the outside - the same materials are used as for the facades of traditionally erected buildings. The dimensions of a typical sea container are as follows: length $12.2 \mathrm{~m}$; a width of $2.4 \mathrm{~m}$; height $2.9 \mathrm{~m}$. Preparation of the foundation depends on the location conditions, and it is usually sufficient to level it on concrete blocks on a stable ground (previously stabilized). In the case of a larger object, e.g. a residential house, footings are made. Reinforced concrete is poured at the supporting points (up to the frost level), thus reducing the impact of ground action on the building foundation. Elimination of traditional foundations saves a lot of money in constructing the house. Due to their functionality, container houses are usually built of two modules. At the bottom there is a day zone with a kitchenette and a toilet, above there is a night zone connected by a staircase. High, panoramic windows allow the natural landscape to enter freely from the outside to the inside. Thanks to this, we take care of our mental and physical health 

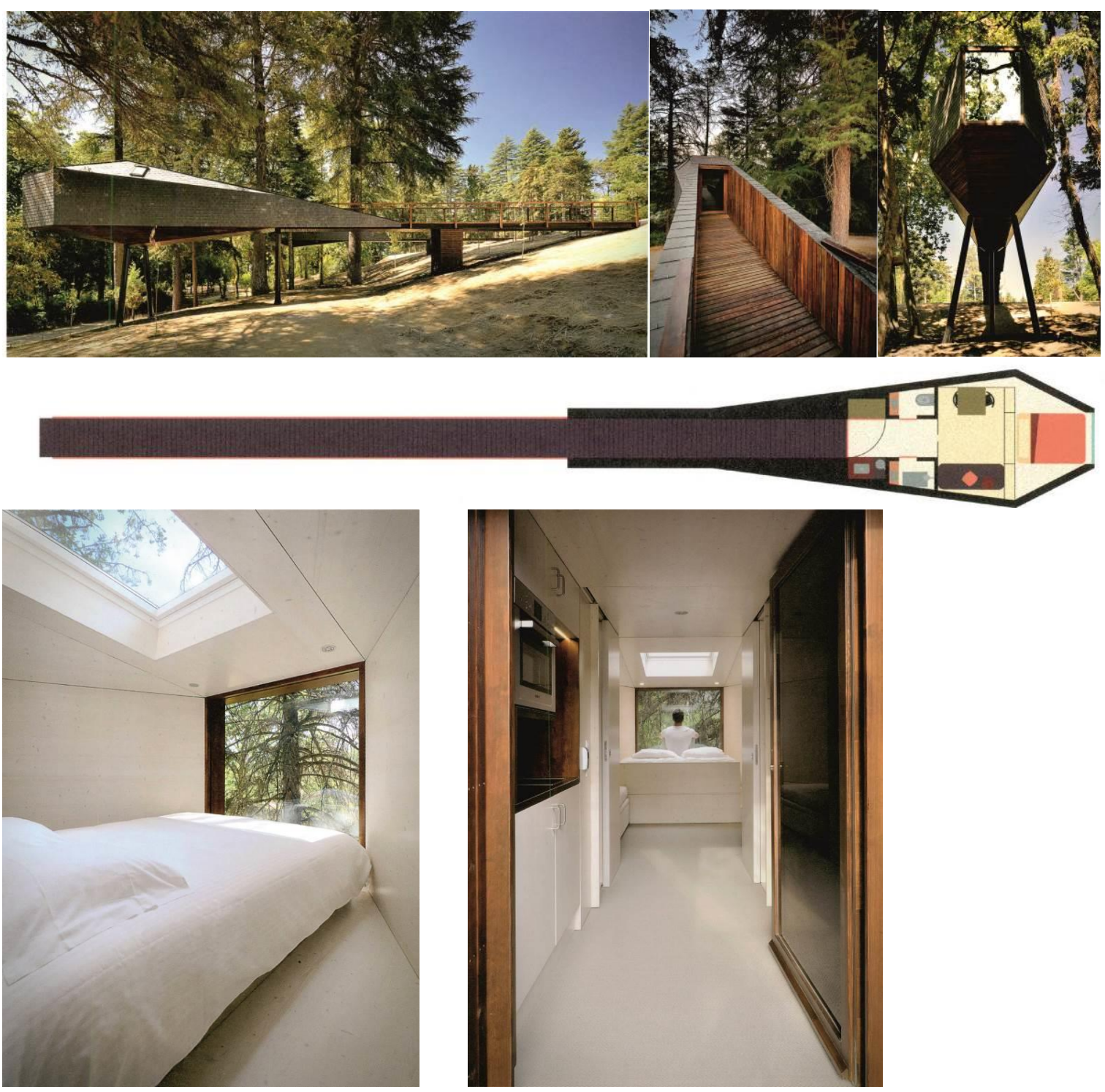

Fig. 13, 14, 15,16,17,18. Portugal, "Tree snake house", designer: Pedras Salgades, $27 \mathrm{~m}^{2}$, with a bridge $66 \mathrm{~m}^{2}, 2013$. Source: Jodidio P. 2014, pp. 399-405

Ryc. 13, 14, 15,16,17,18 Portugalia, "Tree snake house", projektant: Pedras Salgades, 27 m², z mostem 66 m², 2013. Źródło: Jodidio P. 2014, pp. 399-405

Atypical wooden houses erected on stilts (Fig. 13,14,15,16,17,18) are another very interesting example of mini-houses. The objects of this type can be placed on any ground, also in areas such as mountain areas, floodplains or mining areas, where traditional foundation is difficult or impossible to be made. The stilt foundation is safer and much cheaper solution in the case of the above-mentioned types of substrate. Despite enormous advances in building construction, traditional solution as a house on stilts is still popular. As it can be seen in the presented example, the building is placed on stilts and is integrated into the surrounding landscape. It looks like a tree house. Inside, in the day zone you will find a large panoramic window and a skylight, so that nature can enter the interior. The house was designed with the use of solar panels and reuse of water. The structure reflects a primitive hut and is a reference to wild animals 


\section{SUMMARY}

As noted by E. Niezabitowska - An architectural object, among the traditional architects, is perceived as a work of art, despite the fact that reality gives us a lot of evidence that among the architectural objects in which we live, there are very few or no at all the real works of art (Niezabitowska E. 1999, p. 40). Ensuring the safety, health, comfort and beauty is the goal to be achieved in shaping a healthy living environment. The health-promoting features of the housing environment should be strongly expressed in the assessment of the housing environment quality. The above examples show that it is possible to design an interesting, economic architecture of mini-houses using simple materials and simple methods, thanks to which the object can be integrated into the landscape. At the same time, we observe change in the purposes for which residential buildings are designed. Currently, they do not only serve as a shield against external conditions, but more and more often express the personality and views of their users. The design and construction of small mobile houses on wheels, modular ones or built on stilts, will be further developed. They constitute the future direction of architecture, as they include energy-saving or passive solutions, which are currently the most desirable features for residential buildings. At the same time, mini-houses are an ideal solution for young people who, when looking for a job, will not be able to afford high loan instalments associated with the flat purchase. It is scientifically proven that the surrounding landscape and the natural environment have a positive effect on our well-being and health. Proper designing of a limited space, its functionality and ecologic solutions require an appropriate approach, hence it can be assumed that the trend of mini-houses is an opportunity and a challenge for architects.

\section{CONCLUSIONS}

The examples of designing mini-houses presented in the article constitute a new trend in Poland, which is now under significant development. Observing its development in the United States and Europe, it can be stated that it has a good chance of gaining favour with the public. Erecting small, functional, ergonomic houses is a response to the expectations of a conscious, modern and proecological society. In a residential environment, it is essential to maintain a balance between all elements to achieve the well-being of residents and create the conditions for maintaining health in all its aspects. Undoubtedly, the natural environment provides us with stimuli that accelerate regeneration after physical and mental fatigue, improve intellectual performance, improve mental and physical well-being. In addition to aesthetic values, humans show the need to live in symbiosis with nature. Additionally, by using the modern solutions of everyday life, such as the Internet, television, mobile phone or intelligent heating as well as electricity and water supply systems, we are able to create a comfortable, modern living unit. The theory of Thoreau and later of Le Corbusier is still valid. The idea of returning to nature is all the more widespread today, when what is left of wildlife is seriously threatened by urbanization or the substances that "modern" life spreads in air and water According to the author, designing the small, minimalist houses will be a timeless trend in contemporary architecture. Such houses are an excellent investment for young people taking their first steps in professional careers, as well as for the elderly, for whom a simple, functional, small apartment away from the hustle and bustle is a perfect solution. The functionality and economy of such houses make it a good investment for people of all ages. The "Tiny House" movement and minimalism, as can be seen from the above article, is a trend that is only just beginning to shape in Poland. To repeat after L. Kamionka: By shaping the environment, we shape ourselves. By creating the space around us, we try to create the best possible conditions for our life, using its resources for our benefit. Quality of use and aesthetic values are the values of sustainable architecture directly perceived by the community (Kamionka L. 2019 p. 20). The growing awareness of the society in environmental protection, rejection of the consumptive lifestyle and pro-economic attitude, constitute the basic foundations on which the architecture of mini-houses in Poland will develop in the coming years. 


\section{„MAŁE JEST PIĘKNE” NOWE TENDENCJE PROJEKTOWANIA ARCHITEKTURY I WNĘTRZ}

\section{WPROWADZENIE}

Jak w ostatnich latach zmieniło się postrzeganie architektury? Czy zmieniły się w tym zakresie upodobania społeczeństwa? Jak architekci mogą pomóc społecznościom, wśród których żyją? Coraz powszechniejsze działania na rzecz ochrony środowiska, wzrost świadomości oddziaływania człowieka na przyrodę oraz popularyzacja minimalistycznego podejścia do życia spowodowały, że zmieniło się także podejście do koncepcji domu, jako siedziby. Jednocześnie w czasach kryzysu gospodarczego społeczeństwo coraz częściej wybiera małe, ekonomiczne domy, często energooszczędne czy pasywne. Wszystkie te czynniki przyczyniły się do rozwoju koncepcji budowy małych domów (ang. Tiny Houses), stanowiących odpowiedź na oczekiwania współczesnego, świadomego własnego oddziaływania na środowisko społeczeństwa.

\section{METODYKA}

W artykule posłużono się metodą analizy literatury oraz dokumentacji w celu pokazania, jak rozwija się nowa tendencja architektury, związana z projektowaniem przestrzeni mieszkalnych na ograniczonej powierzchni. Zgodnie z zapisem artykułu 29 Prawa budowlanego pozwolenia na budowę nie wymaga budowa (m.in.): wolnostojących parterowych budynków rekreacji indywidualnej, rozumianych jako budynki przeznaczone do okresowego wypoczynku, o powierzchni zabudowy do $35 \mathrm{~m}^{2}$, przy czym liczba tych obiektów na działce nie może przekraczać jednego na każde $500 \mathrm{~m}^{2}$ powierzchni działki (Ustawa Prawo budowlane). Budowa małego domku nie wymaga zatem czasochłonnego załatwiania biurokratycznych formalności. Gdy tylko pozwala na to miejscowy plan zagospodarowania przestrzennego możliwe jest, wyłącznie na podstawie zgłoszenia, postawienie niewielkiego budynku mieszkalnego. Z założenia powinien być to budynek rekreacji indywidualnej, jednakże poprzez zastosowanie odpowiednich rozwiązań możliwe jest przystosowanie takiego obiektu do całorocznego użytkowania. Tym samym małe domy stają się doskonałą alternatywą dla drogiego mieszkania w dużym mieście. Warto także wspomnieć, że dostosowanie mini-domu do potrzeb jego użytkowników wymaga także odpowiedniego zaplanowania jego przestrzeni. Rozkładane stoły, wysuwane ławki czy szuflady ukryte w tajnych zakamarkach, stanowią powszechnie stosowane w minidomach rozwiązania.

\section{PRZEGLĄD LITERATURY}

Zagadnienia małych domów są dość szeroko opisywane w literaturze zagranicznej, dotyczącej nie tylko architektury, lecz także technologii, budownictwa, a nawet socjologii. Warto wskazać, że tematyką tą zajmował się $\mathrm{m}$. in. Michael Joseph Stratton II w monografii pod tytułem „Development of a Tiny House Design Tool To Increase Safety, Efficiency, and Cost-Effectiveness" gdzie omówiono techniczne podejście projektowania małych domów biorąc pod uwagę klimat oraz efektywność energetyczną budowli. Z kolei Daniel Hutchinson w artykule pod tytułem „Struggling for Spatial Authenticity: an analysis of the tiny house movement" czy Jasmine Ford i Lilia Gomez-Lanier w artykule pod tytułem „Are Tiny Homes Here to Stay? A review of Literature on the Tiny House Movement” nakreślają zalety zamieszkania w małych domach. Wśród autorów krajowych na temat nurtu minimalistycznego w architekturze pisał Arkadiusz Wyrzykowski w artykule „Tiny houses czyli projektowanie (nie) minimalistyczne", pokazują historię oraz sposób podejścia do tematyki budowy małych domów (Wyrzykowski A. 2019, s. 85-106) jak również segregując je ze względu na specyfikę i umiejscowienie. Zagadnieniami związanymi z architekturą mini-domów zajmowała się także Agata Twardoch z Politechniki Śląskiej w artykule „Mniej znaczy więcej, czyli mniej za więcej. Przestrzenie społeczne i psychologiczne ujęcie kwestii mikroapartamentów", gdzie autorka nakreśliła problematykę mikroapartamentów w ujęciu przekrojowym zajmując się zarówno historią - obrazując aktualne trendy, jak również pokazując uwarunkowania demograficzne, społeczne i psychologiczne życia na 
niewielkiej powierzchni. Minimalizm jak również projektowanie małych domów w Polsce jest zjawiskiem coraz bardziej powszechnym. Ludzie zapragnęli żyć wygodnie i ekonomicznie czerpiąc $z$ udanych wzorców architektury światowej. Wyżej wymieniony przegląd literatury obrazuje jakie są tendencje projektowania na świecie i jakie zalety wynikają z życia na niewielkiej powierzchni. Autorka w swoim artykule stara się zobrazować możliwości techniczne, społeczne i ekonomiczne projektowania mini-domów w Polsce.

\section{CEL ARTYKUŁU}

Czy ograniczenia przestrzenne w Polsce pozwalaja na wybudowanie ciekawych architektonicznie budynków spełniających wymagania użytkowników? Czy nowy nurt społeczeństwa pro-ekologicznego zrewolucjonizuje spojrzenie na architekturę? Czy niewielki metraż domu może nam dać poczucie bezpieczeństwa? Jak projektować aby wytworzyć strukturę funkcjonalno-przestrzenną, która dostarczy nam odpowiednich warunków estetycznych, zapewni zdrowie psychiczne, zapewni szybsza regenerację, sprawność intelektualną? Czy jesteśmy w stanie zapewnić sobie wszystkie nowoczesne udogodnienia na małej powierzchni? W ostatnich latach zmieniły się zapatrywania na świat, jak również potrzeby natury fizycznej czy psychologicznej. Ludzie zaczęli w nowy sposób oceniać własną przestrzeń życiową - dom i jego otoczenie. Zmieniło się także pojęcie pojmowania architektury, która obecnie powinna być przede wszystkim funkcjonalna. Odzwierciedleniem zmieniających potrzeb stały się małe domki do $35 \mathrm{~m}^{2}$, które w Polsce można postawić bez pozwolenia na budowę, a jedynie na podstawie zgłoszenia (Ustawa z dnia 7 lipca 1994 r. Prawo budowlane art. 29, Tj. Dz. U. 2020, poz. 1333). Domki często są wyposażane w meble wielofunkcyjne na indywidulane zamówienie użytkowników, które spełniłyby potrzebę funkcjonalności architektury. Dostrzeżenie tych zmian sprawiło, że architekci zapragnęli mieć swój wkład w nowy rozdział architektury, jakim jest projektowanie budynków mieszkalnych o bardzo ograniczonej powierzchni.

\section{GENEZA POWSTANIA MINIMALIZMU}

Zgodnie z definicją zaproponowana przez A. Twardocha: Minimalizm to droga do prostoty, ograniczenia niepotrzebnych rzeczy, czynności i obowiązków w każdej dziedzinie naszego życia. Minimalizm jest też manifestem i modą: wyrzucić wszystko co niepotrzebne, porzucić konsumpcyjny tryb życia, być eko. Ma również wymiar symboliczny: mieszaninę historii, hipsterstwa, ekologii, oszczędności i moralności. Sprawia, iż mieszkańcy domów minimalistycznych mogą pozwolić sobie na poczucie wyższości znacznie przekraczające niewielki metraż mieszkania (Twardoch A. 2017, s. 111). Minimalizm czyni życie prostszym i je uporządkowuje. W 19845 amerykański filozof Henry Dawid Thoreau wybudował niedaleko Concord w Massachusetts kabinę, w której mieszkał przez 14 miesięcy. Pod wieloma względami jego filozofia symbolizuje powody, dla których mężczyźni i kobiety szukaja schronienia $w$ bardzo małych domach, $z$ dala od stresu i zanieczyszczenia miast. Kiedy nadmiar i „luksus” są siła napędową niektórych społeczeństw, coraz więcej ludzi odczuwa potrzebę ze skalowania do absolutnego minimum, życia w otoczeniu natury, wśród dźwięków lasu, naprzeciw wchodzącego słońca. Tam, gdzie rozumowanie Thoreau miało związek z filozofią życia, była to próba powrotu do podstaw, motywacji, która wydaje się również rządzić Cabanon de vacances zbudowanym w latach 1951-1952 w Roquebrune-Cap-Martin na Riwierze Francuskiej przez twórcę minimalizmu Le Corbusiera (Ryc. 1,2,3,4). Projekt obiektu o wymiarach 3,66m $\times 3,66 \times 2,66 \mathrm{~m}$, jest uważany za najmniejszy przykład modułowego myślenia i znormalizowanych metod konstrukcyjnych jego autora, który nazwał go maison (home) - ponieważ wział pod uwage jego naturalne otoczenie. Dla Le Corbusiera był to eksperyment oparty na idei Modułu Corbu, systemu ludzkich proporcji, który wymyślił w 1943. Pomimo prostoty Cabanon jest wynikiem dogłębnego myślenia z wyposażeniem ułożonym w spiralny wzór. Przykład Thoreau i Le Corbusiera ilustruje, że najważniejszym czynnikiem kabin jest połączenie filozofii i architektury (Jodidio P. 2014, s. 7). Kabina jak sama nazwa wskazuje miała być domem połączonym z naturą. Za początek projektowania minimalistycznych, małych domów uważa się falę Tiny Houses, która pojawiła się w Stanach Zjednoczonych kilkadziesiąt lat temu. Była to prawdziwa „moda”, czy też - jak określają ją niektórzy autorzy - „fenomen”. Tiny House to 
w dosłownym tłumaczeniu malutki dom. Określenie „small-house movement lub Tiny house movement" stosuje się do ruchu społecznego i architektonicznego dotyczącego mieszkania w małych domach, powiązanego $z$ anytkonsumpcjonizmem. Były to mobilne domy o powierzchni od kilkunastu do góra trzydziestu metrów kwadratowych zbudowane najczęściej z kontenerów morskich, konstrukcji szkieletowej, naczep lub przyczep. Domy te wyposażone były w meble wielofunkcyjne, zamawiane na wymiar: chowane w podłodze szuflady, składany stół, rozkładaną sofę z różnorakim miejscem do przechowywania. Często posiadały miejsce do spania w postaci antresoli nad częścią kuchenno-sanitarną. Warto podkreślić, że niektórzy autorzy upatrują początków nurtu minimalistycznego w Japonii. Na przykład N. Pollock wskazuje, że Japończycy, jak nikt inny, opanowali zdolność do budowania udanych przestrzeni mieszkalnych na bardzo małych działkach. Ze względu na ograniczony obszar na płaskich powierzchniach i hordy ludzi, którzy chcą tam mieszkać, ziemia jest bardzo cenna, szczególnie w Tokio i innych wielkich miastach, gdzie ceny nieruchomości pozostaja niezmiennie wysokie, pomimo wzlotów i upadków gospodarki w tym kraju (Pollock N. 2015 s. 5 ). W Japonii - gdzie niezwykle cenny jest każdy centymetr powierzchni - dom musi być niewielki i funkcjonalny. Młode pokolenie architektów japońskich ma jednak dużo bardziej odważne i niekonwencjonalne podejście i tworzy projekty, które są zadziwiające. To oni zapoczątkowali epokę ciągłego eksperymentowania: zaskakujące kąty ścian, elewacje, którym bliżej do statków kosmicznych czy mądre wykorzystanie okien o najdziwniejszych kształtach. W Polsce wzornictwo wielofunkcyjne narodziło się w latach 30-tych XX wieku, kiedy to zaistniała potrzeba aranżowania bardzo małych mieszkań. Łącząc doświadczenia z odległych części globu - Ameryki i Japonii, narodziła się w Polsce koncepcja projektowania wielofunkcyjnych przestrzeni życiowych, które są przy tym minimalistyczne.

\section{ROZWIAZANIA NA POSZUKIWANIE EKONOMICZNEJ PRZESTRZENI MINI DOMÓW}

Pojawienie się nowych oczekiwań społeczeństwa - małych, funkcjonalnych i ekonomicznych domów spowodowało, że zaczęto szukać jak najprostszych rozwiązań, które te oczekiwania zaspokoją. Pewnym rozwiązaniem stały się domki modułowe, szkieletowe drewniane lub kontenerowe. Dzięki dobrej izolacji termicznej, domy te odznaczają się bardzo dużą energooszczędnością, co stanowi jedno z najważniejszych kryteriów współczesnych użytkowników.

W krajach Europy czy Ameryki Północnej, czyli w rejonach wysoko rozwiniętych, w których mieszkańcy doświadczają wszystkich przywilejów i niedogodności mieszkania w silnie zurbanizowanej przestrzeni, preferencja dla scenerii naturalnej jest niepowtarzalna. Określenie „naturalny” lub „stworzony przez człowieka" staje się ważnym elementem w percepcji i kategoryzacji środowiska zewnętrznego.(Schneider-Skalska G. 2004, s. 54). Elementy naturalne w środowisku mieszkaniowym są preferowane. Udowodnione zostało działanie lecznicze elementów natury w środowisku człowieka. Zarówno ma to wpływ na jego samopoczucie psychiczne i fizyczne, jak i sprawność intelektualną, chęć działania, szybszą regenerację po zmęczeniu psychicznym i umysłowym, przyspieszenie powrotu do zdrowia w przypadku choroby. Projektując strukturę funkcjonalno-przestrzenną dostarczamy wartości estetycznych, identyfikacyjnych, stymulujących, stwarzając warunki do realizacji potrzeby kontaktów z innymi i intymności, niezależności i współpracy.

Mini domy modułowe najczęściej nie wymagaja wykonania fundamentów, a jedynie tymczasowego przyłącza prądu i wody np. z sąsiedniego obiektu. Ścieki mogą być odprowadzane za pomocą pompy, lub do zbiornika typu szambo. Obecnie domy modułowe są najczęściej produkowane pod potrzeby domków letniskowych w miejscach bliskich naturze jak np. nad jeziorem, w lesie (Ryc. 5, $6,7,8,9)$. Kontakt $z$ natura jest tym wyznacznikiem, który daje nam zdrowie psychiczne, spokój, ukierunkowuje rozwój intelektualny. Wiele osób decyduje się również na posadowienie całorocznych domów letniskowych w centrach miast na ogródkach działkowych. W dużych aglomeracjach miejskich na zachodzie Europy, popularny stał się również wynajem placów w centrach miast przez firmy w celu posadowienia kilkunastu całorocznych domów modułowych pod dalszy wynajem. Mini domy modułowe wykonane są z prefabrykatów, czyli gotowych elementów wykonanych w fabryce. Do prefabrykatów zaliczyć możemy ściany czy stropy, ale również większe elementy stanowiące nawet połowę domu. Budynki te najczęściej wykonywane są w dwóch konstrukcjach: szkieletowej, gdzie rdzeń stanowi drewno lub stal, albo wykonanej z keramzybetonu, czyli stalowej ramy wypełnionej 
wypaloną gliną zmieszaną z betonem. Gotowe domy modułowe składają się z określonych komponentów, które na placu budowy są ze sobą łączone na specjalnie przygotowanych fundamentach. Budowa nie wymaga zatrudnienia inspektora nadzoru, a stopień zaawansowania prac nie jest uzależniony od warunków atmosferycznych. Na rynku dominuje oczywiście technologia szkieletu drewnianego z uwagi na łatwość wykonania, lekkość i wytrzymałość konstrukcji. Domy modułowe o konstrukcji keramzytobetonowej są mniej popularne, z uwagi na wyższy koszt produkcji i transportu. Niezależnie od rodzaju technologii przyjętej do produkcji domku, jego trwałość będzie porównywalna do typowego domu jednorodzinnego, dzięki zastosowaniu w tych obiektach odpowiednich zabezpieczeń i izolacji termicznych ścian i stropów, oraz izolacji ochronnych. Warto przy tym podkreślić, że domy modułowe z betonu będą wykazywały się trochę wyższą trwałością, odpornością ogniową i wysoką akumulacją ciepła, czyli parametrami, którymi wyróżniają się domy murowane. A zatem, jeśli mini-dom ma spełniać funkcję całorocznego lokum korzystne jest zainwestowanie w dom modułowy wykonany z keramzybetonu. Rozwój budownictwa modułowego, zmiana technologii oraz wysoki stopień prefabrykacji sprawiły, że domy te przestały kojarzyć się już z tanimi kontenerami bez wyrazu i coraz częściej przypominają nowoczesne, całoroczne obiekty. Budynki modułowe już dawno przestały być obiektami sezonowymi. Aktualna technologia oraz materiały pozwalają na tworzenie całorocznych budynków, dla których jedyną pracą murowaną jest wylanie płyty fundamentowej. Nowoczesne domy modułowe są nie tylko atrakcyjne wizualnie i świetnie wpasowują się w pejzaż miejskiej architektury, ale również coraz częściej spełniają standardy budownictwa energooszczędnego. Redukują opłaty związane z zapotrzebowaniem na energię cieplną, a rozwiązania zastosowane do montażu oraz prefabrykacji pozwalają również obniżyć koszt eksploatacji budynku. Niektóre z nowoczesnych domów modułowych mogą posiadać samodzielny system ogrzewający oraz systemy inteligentne. Wnętrza takiego domu charakteryzują się funkcjonalnością w projektowaniu struktury użytkowej jak i w elementach wyposażenia wnętrza. Nowoczesne wnętrza są tak projektowane aby środowisko naturalne mogło przenikać z zewnątrz do wnętrza. Zapewniają to duże, modułowe okna, często także połaciowe. Dzięki temu mieszkając w małym domu mamy poczucie bezpieczeństwa ale także wykorzystujemy otaczający nas krajobraz w celu zrelaksowania się, uspokojenia, wyciszenia.

Innym ciekawym rozwiązaniem są domy modułowe - kontenerowe (Ryc. 10,11,12). Do ich budowy wykorzystuje się kontenery morskie, nowe lub używane. Konstrukcja kontenera to samonośna rama stalowa (pełniąca funkcję szkieletu) wykonana z profili zamkniętych, walcowanych. Profile są piaskowane i zabezpieczone antykorozyjną powłoką lakierniczą. Ściany zewnętrzne, sufit i podłoga wykonane są z ocynkowanej blachy, usztywnionej bocznymi wzmocnieniami i wypełnione materiałem izolacyjnym. Jest to przeważnie wełna mineralna lub izolacja poliuretanowa $w$ formie sztywnych płyt PUR. Warto podkreślić, że kontenery ociepla się w ten sam sposób i tymi samymi materiałami, co budynki tradycyjne. Od wewnętrznej strony przegród stosuje się płyty wiórowe, laminowane lub płyty gipsowo-kartonowe. Jeśli chodzi o wykończenie domu z kontenerów od zewnątrz, możliwości jest wiele - stosuje się te same materiały jak przy elewacjach budynków wznoszonych tradycyjnie. Wymiary typowego kontenera morskiego to: długość $12,2 \mathrm{~m}$; szerokość 2,4 m; wysokość $2,9 \mathrm{~m}$. Przygotowanie posadowienia zależy od warunków lokalizacji i na ogół wystarcza wypoziomowanie na betonowych bloczkach na stabilnym gruncie (wcześniej ustabilizowanym). W przypadku większego obiektu, np. domu mieszkalnego, wykonuje się stopy fundamentowe. W punktach podparcia wylewa się beton zbrojony (do poziomu przemarzania), niwelując w ten sposób wpływ pracy gruntu na właściwe posadowienie budynku. Możliwość rezygnacji z tradycyjnych fundamentów stanowi sporą oszczędność kosztów budowy domu. Domy kontenerowe ze względu na swą funkcjonalność zbudowane są najczęściej $z$ dwóch modułów. Na dole znajduje się strefa dzienna $z$ aneksem kuchennym i wc, powyżej połączona klatką schodową, strefa nocna. Wysokie, panoramiczne okna zapewniają swobodny przepływ krajobrazu naturalnego z zewnątrz do wewnątrz. Dzięki temu dbamy o nasze zdrowie psychiczne i fizyczne.

Kolejnym, bardzo ciekawym przykładem mini-domów, mogą być nietypowe domy drewniane stawiane na palach (Ryc. 13,14,15,16,17,18). Obiekty tego rodzaju można stawiać na każdym podłożu, również na obszarach takich, jak tereny górskie, zalewowe czy górnicze, na których położenie tradycyjnej podbudowy jest utrudnione lub niemożliwe. Fundament palowy jest bezpieczniejszym, 
a także dużo tańszym rozwiązaniem w przypadku wymienionych rodzajów podłoża. Mimo ogromnych postępów w budownictwie takie tradycyjne, rozwiązanie jak dom na palach dalej jest popularne. Jak widać w załączonym przykładzie, dzięki posadowieniu na palach budynek staje się ściśle wkomponowany w otaczający go krajobraz. Przypomina nijako domek na drzewie. Wewnątrz w strefie dziennej znajdziemy duże panoramiczne okno oraz świetlik dachowy tak aby przyroda mogła wejść do wnętrza. Dom zaprojektowany został z użyciem paneli solarnych oraz z ponownym wykorzystaniem wody. Struktura odzwierciedla prymitywną chatę oraz stanowi nawiązanie do dzikich zwierząt.

\section{PODSUMOWANIE}

Jak zauważa E. Niezabitowska - Obiekt architektoniczny, w tradycyjnym środowisku architektów jest postrzegany jako dzieło sztuki pomimo, że rzeczywistość daje nam wiele dowodów na to, że wśród obiektów architektonicznych w jakich nam przyszło żyć prawdziwych dzieł sztuki jest bardzo niewiele albo nie ma ich wcale (Niezabitowska E. 1999, s. 40). Celem do osiagnięcia w kształtowaniu zdrowego środowiska mieszkaniowego jest zapewnienie bezpieczeństwa, zdrowia, wygody i piękna. Prozdrowotne cechy środowiska mieszkaniowego powinny być mocno wyartykułowane $w$ ocenie jakości środowiska mieszkaniowego. Powyższe przykłady pokazują, że można zaprojektować ciekawą, ekonomiczną architekture mini domów wykorzystując do tego proste materiały oraz proste sposoby, dzięki którym można wkomponować obiekt w krajobraz. Jednocześnie obserwuje się przesunięcie celów, dla których projektuje się budynki mieszkalne. Obecnie nie spełniają one wyłącznie roli osłony przed warunkami zewnętrznymi, lecz coraz częściej stanowią wyraz osobowości oraz poglądów jego użytkownika. Projektowanie i budowanie małych domów mobilnych na kółkach, modułowych czy takich posadowionych na palach będzie ulegało dalszemu rozwojowi. Stanowią one bowiem przyszłościowy kierunek architektury, albowiem obejmuje on rozwiązania energooszczędne czy pasywne, które obecnie są najbardziej pożądanymi cechami dla budynków mieszkalnych. Jednocześnie mini-domy stanowią idealne rozwiązanie dla młodych ludzi, którzy szukając pracy nie będą $w$ stanie pozwolić sobie na wysokie raty kredytu, wiążące się z zakupem mieszkania. Jest udowodnione naukowo, iż otaczający nas krajobraz oraz środowisko naturalne wpływa korzystnie na nasze samopoczucie i zdrowie. Odpowiednie zaplanowanie ograniczonej przestrzeni, jej funkcjonalność oraz ekologiczność rozwiązań wymagaja odpowiedniego podejścia, stąd też można sądzić, że w fenomenie mini-domów tkwi szansa i wyzwanie dla architektów.

\section{WNIOSKI}

Przedstawione w artykule przykłady projektowania mini-domów stanowią w Polsce nowe zjawisko, które podlega znaczącemu rozwojowi. Obserwując jego rozwój w Stanach Zjednoczonych oraz w Europie można stwierdzić, że ma on duże szanse uzyskania przychylności społeczeństwa. Stawianie małych, funkcjonalnych, ergonomicznych minii domów jest bowiem odpowiedzia na oczekiwania świadomej, nowoczesnej oraz nastawionej proekologicznie grupy ludności. W środowisku mieszkaniowym niezbędne jest zachowanie równowagi pomiędzy wszystkimi elementami w celu osiągnięcia dobrego samopoczucia mieszkańców i stworzenia warunków do zachowania zdrowia w każdym jego aspekcie. Niewatpliwie środowisko naturalne dostarcza nam bodźców, które przyspieszają regenerację po zmęczeniu psychicznym i umysłowym, poprawiaja sprawność intelektualną, poprawiają samopoczucie psychiczne i fizyczne. Poza wartościami estetycznymi człowiek wykazuje zapotrzebowanie na życie w symbiozie z naturą. Dodatkowo stosując najnowocześniejsze rozwiązania dnia codziennego takie jak Internet, telewizja, telefon komórkowy czy inteligentne systemy ogrzewania, dostarczania prądu czy wody, jesteśmy w stanie stworzyć komfortową, nowoczesną jednostkę mieszkalną. Teorią Thoreau a później Le Corbusiera jest dalej aktualna. Idea powrotu do natury jest tym bardziej rozpowszechniona dzisiaj, gdy to, co pozostało z dzikiej przyrody, jest poważnie zagrożone przez urbanizację lub substancje, które „nowoczesne” życie rozprzestrzenia w powietrzu i wodzie. Zdaniem autorki projektowanie małych, minimalistycznych domów będzie stanowiło ponadczasowy nurt we współczesnej architekturze. Stanowią one doskonałą inwestycję zarówno dla młodych stawiających pierwsze kroki w karierze zawodowej, jak również dla osób star- 
szych, dla których proste, funkcjonalne, małe mieszkanie z dala od zgiełku stanowi idealne rozwiązanie. Funkcjonalność i ekonomiczność takich domów sprawiają, iż będzie to dobra inwestycja dla osób w każdym wieku. Ruch „Tiny House” i minimalizm jak widać z powyższego artykułu jest to tematyka, która w Polsce dopiero zaczyna się kształtować. Powtarzając za L. Kamionką: Kształtując środowisko, kształtujemy samych siebie. Kreując przestrzeń wokół nas, staramy się stworzyć jak najlepsze warunki dla naszego życia, wykorzystując jego zasoby na nasz użytek. Walory architektury zrównoważonej bezpośrednio odbierane przez społeczność to jakość użytkowania i walory estetyczne (Kamionka L.2019 s. 20). Wzrastająca świadomość społeczeństwa w zakresie ochrony środowiska, odrzucenie konsumpcyjnego stylu życia oraz proekonomiczne nastawienie stanowią podstawowe podwaliny, na których architektura mini-domów w Polsce będzie się rozwijać w najbliższych latach.

\section{BIBLIOGRAPHY}

Blake P. 1991 Mies van der Rohe Architektura i struktura. wyd. Artystyczne i Filmowe, Warszawa, ISBN 83221-0540-1

Galindo M. 2010, Contemporary Prefab Houses. wyd. Braun Publishing AG, Salenstein, Switzerland ISBN 9783-03768-066-7

Jodidio P. 2014, Cabins / Hutten/ Cabanes. 2014. Wyd. Taschen GmbH, Koln, Germany, ISBN 9783836565011

Kamionka L. 2019 Architektura w zrównoważonym środowisku kulturowo-przyrodniczym. Wyd. Politechnik Świętokrzyskiej. Kielce. ISBN 978-83-657 19-66-9

Niezabitowska E. A. 1999 Ocena jakości z pozycji dostawcy i odbiorcy. JAKOŚC ŚRODOWISKA ZBUDOWANEGO, tom. 2, s. 39-44, wyd. Politechniki Śląskiej

Pollock N. 2015, Jutaku: Japanese Houses. Wyd. Phaidon, ISBN 978071486929

Schneider-Skalska G. 2004 Kształtowanie zdrowego środowiska mieszkaniowego. Wybrane zagadnienia. Politechnika Krakowska im. Tadeusza Kościuszki Kraków. Monografia 307

Twardoch A. A. 2017 Mniej znaczy więcej, czy mniej za więcej. Przestrzenne, społeczne i psychologiczne ujęcie kwestii mikroapartamentów. TEKA KOMISJI URBANISTYKI I ARCHITEKTURY PAN ODDZIAŁ W KRAKOWIE, Tom XLV, s. 07-122

Ustawa z dnia 7 lipca 1994 r. Prawo budowlane, Tj. Dz. U. 2020, poz. 1333.

Wyrzykowski A. A. 2019 Tiny houses czyli projektowanie (nie)minimalistyczne. PRZESTRZEŃ, EKONOMIA, SPOŁECZEŃSTWO, Numer 15/l, s. 85-106, wyd. Sopocka Szkoła Wyższa

\section{AUTHOR'S NOTE}

The author graduated from the Silesian University of Technology in Gliwice in the field of architecture and urban planning. Then, she was graduated from interior architecture at the Academy of Fine Arts in Krakow, where she obtained a PhD of Architecture degree. She is a member of the Silesian Chamber of Architects and the Silesian Chamber of Civil Engineers. She has been dealing with the problem of designing for 15 years, working, among others, as an assistant professor at the University of Technology in Katowice as well as running a business.

\section{O AUTORZE}

Autorka ukończyła Politechnikę Śląską w Gliwicach na kierunku Architektura i Urbanistyka. Następnie ukończyła Architekturę Wnętrz na Akademii Sztuk Pięknych w Krakowie, gdzie uzyskała tytuł doktora sztuki. Jest członkiem Śląskiej Izby Architektów oraz Śląskiej Izby Inżynierów Budownictwa. Problemem projektowania zajmuje się od 15 lat, pracując między innymi jako adiunkt na Wyższej Szkole Technicznej w Katowicach oraz prowadząc działalność gospodarczą.

Contact | Kontakt: justynajuroszek@wp.pl 